\title{
Analisis Tingkat Pengetahuan, Sikap Keuangan Pribadi dan Perilaku Keuangan Pribadi Mahasiswa Jurusan Akuntansi Politeknik Negeri Malang
}

\author{
Atika Syuliswati dan Andi Asdani \\ Dosen Politeknik Negeri Malang \\ Jl. Soekarno Hatta Malang \\ E-mail: atikasyuliswati@gmail.com
}

\begin{abstract}
:
Many students still don't understand how to invest or to access the capital markets and money markets, because students don't have enough knowledge about it. Meanwhile, education about personal finance remains as a major challenge in Indonesia. The purpose of this study was to analize of Personal Financial Knowledge, personal finance attitudes, personal finance behavior for 4th year and senior students Accounting Department at State Polytechnic Of Malang. The population in this study were students from Accounting Department at State Polytechnic Of Malang, for 4th year and senior students. Data in the form are primary data and sample were spread as much as 120 for 4 th and 89 for 8 th semester students $(n=209)$. The method that used is descriptive statistics, validity test, reliability test and t-test. Personal financial knowledge and personal behavior finance were significant differences between 4th and 8 th semester students. For personal financial knowledge with significant value 0.000, and personal finance behavior with significant value 0.000. Personal financial attitudes was not significant differences between 4th and 8th semester students. For personal finance attitudes with significant value 0.064 .

Keywords: Personal Financial Knowledge, Personal Finance Attitudes, Personal Finance Behavior
\end{abstract}

\section{PENDAHULUAN}

Pada perkembangannya, pengetahuan mengenai keuangan semakin berkembang dan mulai diperkenalkan di berbagai jenjang pendidikan. Praktek pendidikan keuangan juga sangat dekat dan melekat dengan kehidupan sehari-hari seperti bagaimana mempergunakan pendapatan yang diperoleh dan mengelola pendapatan tersebut untuk investasi ataupun untuk kehidupan sehari-hari. Oleh karenanya pendidikan keuangan baik jika diajarkan diusia dini agar kelak ketika beranjak dewasa, seseorang itu dapat mengaplikasikan ilmu yang didapatkan dengan baik. Sehingga dapat disimpulkan bahwa pengetahuan keuangan dapat digunakan dalam berbagai 
aspek kehidupan manusia, baik untuk sehari-hari maupun untuk jangka waktu yang panjang.

Berdasarkan survey yang dilakukan OJK pada tahun 2013 hanya sebesar $22 \%$ saja masyarakat Indonesia yang memahami literasi keuangan dan 57\% masyarakat Indonesia yang menggunakan fasilitas dan produk jasa keuangan seperti perbankan, asuransi dan instrumen pasar modal. Di pasar modal 15\% masyarakat Indonesia yang menjadi investor. Selain itu survey yang dilakukan oleh OJK juga menyatakan bahwa seseorang dengan latar belakang pendidikan perguruan tinggi memiliki tingkat pemahaman keuangan sebesar 56,4\%, kemudian diikuti oleh pelajar sekolah menengah atas sebesar 35,7\%, sedangkan untuk pelajar di bawah tingkat menengah atas dan tidak bersekolah menunjukkan presentase yang lebih kecil yaitu 24,6\% dan 13,6\% (Otoritas Jasa Keuangan, 2013).

Indeks literasi keuangan di Indonesia sebesar 21,7\% menunjukkan angka yang lebih rendah dibandingkan dengan indeks literasi keuangan di Singapura yaitu 98 persen (Zahroh, 2014). Dari survey yang dilakukan OJK tersebut dapat ditarik kesimpulan bahwa pemahaman yang dimiliki oleh masyarakat Indonesia mengenai produk-produk keuangan masih sangat kurang dan mahasiswa memiliki pemahaman mengenai keuangan yang lebih baik karena latar belakang pendidikannya.

Mahasiswa sering memulai masa kuliah mereka dengan atau tanpa mengerti dan bertanggung jawab terhadap keuangan pribadi mereka sendiri (Behrman et all, 2012). Menurut peneliti senior INDEF, Aviliani, kebutuhan edukasi kepada masyarakat terhadap produk-produk keuangan baik bank maupun nonbank sangat mendesak agar masyarakat tidak tertipu oleh pihak-pihak yang tidak bertanggung jawab. Dirinya melihat bahwa sebenarnya untuk produk-produk pokok bank seperti tabungan, giro, dan deposito, sosialisasi dan edukasi yang dilakukan oleh bank dinilai sudah cukup baik. Namun, untuk produk-produk derivatif dibutuhkan sosialisasi dan edukasi yang lebih intens terutama mengenai risikonya.

Maksud dari keuangan pribadi, bisa juga disebut sebagai manajemen uang atau pembiayaan konsumen, termasuk masalah keuangan individu seperti rencana arus kas, kredit, asuransi, investasi, obligasi, dan tabungan. Dari domain affective, sikap mengacu pada bagaimana seseorang merasakan masalah tentang keuangan pribadi. Dari variabel perilaku, perilaku mengacu pada bagaimana seseorang berperilaku yang berkaitan dengan keuangan pribadi. Dari domain cognitive, pengetahuan mengacu pada apa yang kita tahu tentang masalah keuangan pribadi, bagaimana persepsi tingkat pengetahuan mahasiswa mengenai berbagai konsep keuangan pribadi (Byrne, 2007). Belajar bagaimana mengelola uang (money management) itu 
sama pentingnya (Chen dan Volpe, 1998). Pendidikan keuangan akan membahas isu - isu pribadi yang bersifat keuangan pribadi.

Pengertian sikap keuangan menurut Pankow (2003) sebagaimana dikutip Rita dan Santoso (2010) sesuai pengertian menurut Gitman (2002), yaitu sikap keuangan diartikan sebagai keadaan pikiran, pendapat, serta penilaian tentang keuangan. Sikap keuangan pribadi merupakan kontributor penting untuk kesuksesan atau kegagalan keuangan konsumen. Meskipun demikian, beberapa studi telah dilakukan untuk meneliti pengelolaan keuangan mahasiswa baik dari sikap keuangan pribadi sendiri atau bersamaan dengan pengetahuan keuangan dan perilaku keuangan.

Mahasiswa semester 4 biasanya berumur 18-20 tahun dan telah mengambil sekitar 65 sks. Rata-rata mahasiswa semester 4 telah mengambil mata kuliah manajemen keuangan dan telah mempelajari pengantar bisnis. Penilaian Boyland dan Warren (2013) dalam Zahroh (2014) menilai tentang perbedaan literasi keuangan antara mahasiswa dalam negeri dan mahasiswa internasional. Penelitian dilakukan berdasarkan jenis kelamin dan apakah mahasiswa tersebut berasal dari dalam negeri atau mahasiswa internasional. Dalam survei instrument yang telah dibagi menjadi dua bagian, bagian pertama berisi 31 pertanyaan yang digunakan untuk menguji literasi keuangan yang dibagi menjadi empat kategori: kategori pendapatan, pengelolaan uang, tabungan, dan pengeluaran. Hasil penelitian menunjukkan perbedaan signifikan pada pengelolaan uang dan pengeluaran. Sedangkan untuk pendapatan dan pengetahuan/kebiasaaan untuk menabung tidak terlihat adanya perbedaan yang signifikan.

Mosser (1981) dalam Zahroh (2014) menentukan bagaimana pengetahuan pendidikan mahasiswa community college dan four-year college yang telah mengambil kursus dibandingkan dengan mahasiswa yang tidak mengambil kursus. Selain itu Mosser juga ingin menentukan variabel-variabel apa saja yang mempengaruhi pengetahuan keuangan pribadi mahasiswa. Variabel yang di teliti tersebut adalah usia, jenis kelamin, pengalaman kerja, dan jurusan mereka. Dari penelitiannya tidak ditemukan perbedaan yang signifikan antara mahasiswa community college dan four-year college yang telah mengambil kursus dan community college dan four-year college yang tidak mengambil kursus. Selain itu menurut Mosser, pengetahuan keuangan pribadi juga tidak mempunyai perbedaan yang signifikan dengan jenis kelamin, usia, pengalaman kerja, dan jurusan.

\section{TINJAUAN PUSTAKA}

\section{Pengetahuan Keuangan}

Pemahaman tentang masalah keuangan pribadi lebih dalam lagi, diperlukan pengetahuan keuangan. Literasi keuangan dapat diartikan sebagai 
pengetahuan keuangan, yang memiliki tujuan untuk mencapai kesejahteraan (Lusardi \& Mitchell 2007). Hal tersebut perlu digaris bawahi sebagai persiapan kita nantinya saat globalisasi menyerang. Lebih spesifik lagi dijelaskan, globalisasi dalam bidang keuangan. Kapoor (2011) serta Goss (2001) juga menyatakan bahwa diperlukan pengetahuan tentang bagaimana mengelola keuangan serta bagaimana teknik berinvestasi yang nantinya bisa jadi hal yang tidak dapat diabaikan lagi seperti waktu-waktu seperti sebelum-sebelumnya. Alat keuangan (financial tools) merupakan bentuk dan bagian yang digunakan dalam memutuskan manajemen keuangan pribadi (contohnya seperti cek, kartu kredit, kartu debit, dan uang tunai). Smith (1973) dalam Zahroh (2014) meneliti sikap pembiayaan konsumen dan pecapaian mahasiswa. Setelah eksplorasinya, Smith menyimpulkan bahwa mahasiswa yang menerima pendidikan di bidang keuangan pribadi memiliki pengetahuan yang lebih besar tentang kredit, asuransi, investasi, pengelolaan uang, dan tabungan dibandingkan dengan mereka yang tidak mempunyai dasar pendidikan keuangan pribadi. Salah satu temuan penting Smith menguraikan pengalaman kerja dengan pengetahuan keuangan.

Pernyataan dari Gittman (2002) literasi keuangan adalah seperangkat keterampilan dan pengetahuan yang memungkinkan seorang individu untuk membuat keputusan yang efektif dengan semua sumber daya keuangan mereka. Sedangkan menurut pernyataan dari Rita dan Santoso (2015) menjelaskan bahwa literasi keuangan membantu individu agar terhindar dari masalah keuangan. Selanjutnya menurut Lusardi \& Mitchell tahun 2007 literasi keuangan dapat diartikan sebagai pengetahuan keuangan dengan tujuan mencapai kesejahteraan. Hal ini dapat dimaknai bahwa persiapan perlu dilakukan untuk menyongsong globalisasi, lebih spesifiknya globalisasi dalam bidang keuangan.

Menurut Kapoor (2011) mengartikan bahwa literasi keuangan sebagai kemampuan untuk memahami kondisi keuangan serta konsep-konsep keuangan dan untuk merubah pengetahuan itu secara tepat ke dalam perilaku. Pernyataan dari Tandelilin (2010) menjelaskan literasi keuangan sangat penting karena beberapa alasan, Antara lain (1) Konsumen yang memiliki literasi keuangan bisa melalui masa-masa keuangan yang sulit karena faktanya bahwa mereka mungkin memiliki akumulasi tabungan, membeli asuransi dan diversifikasi investasi mereka, (2) Literasi keuangan juga secara langsung berkorelasi dengan perilaku keuangan yang positif seperti pembayaran tagihan tepat waktu, angsuran pinjaman, tabungan sebelum habis dan menggunakan kartu kredit secara bijaksana. Pensiun, maupun perusahaan investasi. Investor juga mempelajari bagaimana mengelola kesejahteraan investor (investor's wealth) yang bersifat moneter. Kesejahteraan moneter ini dapat dinilai dari penjumlahan pendapatan yang dimiliki saat ini dan nilai saat ini (present value) pendapatan di masa datang. 


\section{Sikap Keuangan}

Sikap keuangan pribadi merupakan kontributor penting untuk kesuksesan atau kegagalan keuangan konsumen. Meskipun demikian, beberapa studi telah dilakukan yang meneliti pengelolaan uang mahasiswa dan sikap keuangan pribadi, baik secara sendiri atau secara bersamaan dengan pengetahuan atau dengan perilaku keuangan. Sikap adalah keadaan mental dan taraf dari kesiapan, yang diatur melalui pengalaman yang memberikan pengaruh dinamik atau terarah terhadap respons individu pada semua objek dan situasi yang berkaitan dengannya. Dengan begitu, pengertian sikap keuangan menurut Pankow (2003) sebagaimana dikutip oleh Rita dan Santoso (2010) sesuai pengertian yang dikembangkan oleh Gitman (2002), yaitu diartikan sebagai keadaan pikiran, pendapat, serta penilaian tentang keuangan. Penelitian lain yang diteliti tentang mahasiswa dan keuangan pribadi yang cenderung punya hubungan dengan pembelian kompulsif. Roberts dan Jones (2001) dalam Zahroh (2014) berusaha untuk menemukan bagaimana sikap keuangan mempunyai peran dalam pembelian kompulsif dikalangan mahasiswa.

\section{Perilaku Keuangan}

Perilaku adalah cara dimana seseorang bertindak atau perilaku diri sendiri. Keuangan pribadi adalah manajemen keuangan seorang individu yang dilakukan untuk mendapatkan anggaran dan tabungan dengan mempertimbangkan berbagai risiko keuangan dan peristiwa kehidupan masa depan. Ketika merencanakan keuangan pribadi individu akan mempertimbangkan kesesuaian dengan kebutuhan nya dari berbagai produk perbankan (giro, tabungan, kartu kredit dan kredit konsumen) atau investasi (pasar saham, obligasi, reksadana), produk asuransi (asuransi jiwa, asuransi kesehatan) dan perencanaan pension. Perilaku keuangan pribadi adalah cara dimana individu mengelola sumber dana (uang) untuk digunakan sebagai keputusan penggunaan dana, penentuan sumber dana (uang) untuk digunakan sebagai keputusan untuk perencanaan pension (Gittman, 2002). Dalam proses pengelolaan tersebut, maka tidak mudah untuk mengaplikasikannya karena terdapat beberapa langkah sistematis yang harus diikuti.

Dengan mengetahui dasar dari manajemen keuangan, maka kita akan tahu bahwa segala sesuatu harus diawali dengan berfikir terlebih dahulu sebelum bertindak. Keputusan keuangan diartikan sebagai proses memilih alternatif tertentu dari sejumlah alternatif (Navickas dan Krajnakova, 2014). Pengertian tersebut mendeskripsikan keterkaitan dengan arti dari manajemen keuangan yaitu bagaimana mendapatkan uang dan bagaimana menggunakannya dengan tepat sehingga ketepatan dalam memilih alternative penggunaan uang menjadi signifikan. Karena pada prinsipnya keputusan keuangan yang diambil bermaksud mengoptimalkan 
kesejahteraan maka pembuatan keputusan keuangan merupakan suatu hal yang kompleks mengingat perlu mempertimbangkan situasi dan informasi secara cermat dengan melakukannya.

Perilaku keuangan (behavior finance) mulai dikenal dan berkembang didunia bisnis dan akademis pada tahun 1990. Berkembangnya behavior finance dipelapori oleh adanya perilaku seseorang dalam proses pengambilan keputusan. Dari beberapa penelitian terdahulu ditunjukkan bahwa financial literacy atau pengetahuan keuangan memiliki hubungan yang positif dengan perilaku keuangan (behavior finance) (Noor, Nurfadhilah, Ramesh, Mion, 2013). Behavior finance adalah suatu perilaku yang berkaitan dengan aplikasi keuangan. Menurut Ricciardi (2000), behavioral finance adalah suatu displin ilmu yang di dalamnya melekat interaksi berbagai displin ilmu dan secara terus menerus berintegrasi sehingga pembahasannya tidak dilakukan isolasi.

Berdasarkan landasan teori, masalah penelitian dan penelitian terdahulu, maka penulis mengembangkan model hipotesis sebagai berikut:

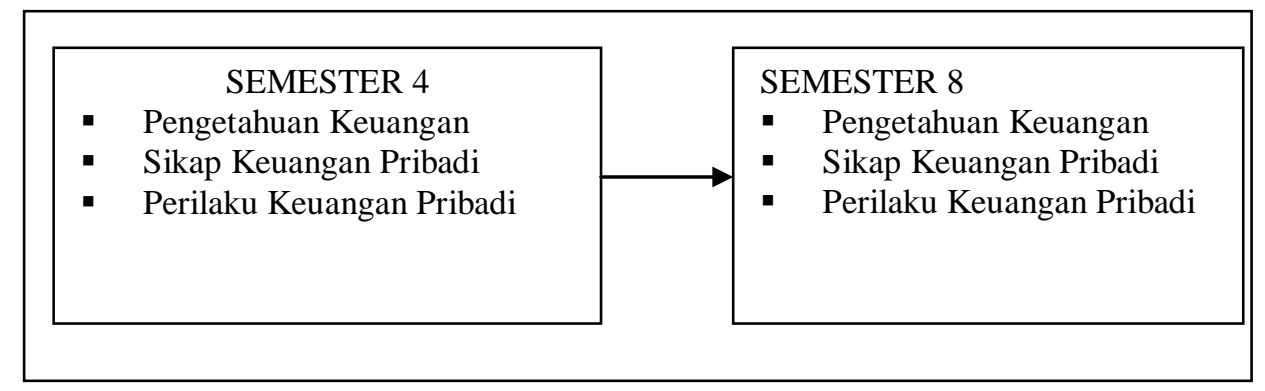

Gambar 1. Model Hipotesis

Berdasarkan model tersebut, maka dapat dirumuskan hipotesis sebagai berikut:

$\mathrm{H}_{1}$ : Ada perbedaan pengetahuan keuangan antara mahasiswa semester 4 dan mahasiswa semester 8 berdasarkan konsep keuangan pribadi.

$\mathrm{H}_{2}$ : Ada perbedaan sikap keuangan pribadi antara mahasiswa semester 4 dan mahasiswa semester 8 berdasarkan konsep keuangan pribadi.

$\mathrm{H}_{3}$ : Ada perbedaan perilaku keuangan pribadi antara mahasiswa semester 4 dan mahasiswa semester 8 berdasarkan konsep keuangan pribadi.

\section{METODE PENELITIAN}

\section{Jenis Penelitian}

Penelitian ini tergolong sebagai deskriptif analitis. Menurut Sekaran (2003) penelitian deskriftif analitis dilakukan untuk mengetahui nilai variabel mandiri, baik satu variabel atau lebih. 


\section{Lokasi dan Rancangan Penelitian}

Penelitian ini dilakukan di wilayah kerja Politeknik Negeri Malang. Jenis penelitian yang digunakan adalah observasional dengan menggunakan desain cross sectional study.

\section{Populasi dan Sampel}

Populasi adalah gabungan dari seluruh elemen yang berbentuk peristiwa, hal, atau orang yang memilki karakteristik yang serupa yang menjadi pusat semesta penelitian (Ferdinand, 2006) sedangkan pendapat Sugiyono (2010) populasi ialah wilayah generalisasi yang terdiri dari atas obyek atau subyek yang mempunyai kualitas dan karakteristik tertentu yang ditetapkan oleh peneliti untuk dipelajari dan kemudian ditarik kesimpulannya. Populasi adalah wilayah yang terdiri atas obyek/subyek yang mempunyai kualitas dan karakteristik tertentu yang ditetapkan oleh peneliti untuk dipelajari dan kemudian ditarik kesimpulannya (Sugiyono, 2010).

Dalam penelitian ini, populasi penelitian mengacu pada mahasiswa diploma 4 jurusan akuntansi politeknik negeri malang semester 4 dan semester 8 berjumlah 438 mahasiswa. Sampel adalah bagian dari jumlah dan karakteristik yang dimiliki oleh populasi (Sugiyono, 2010). Pengambilan sampel dalam penelitian ini dengan teknik probability sampling yaitu proportionate stratified random sampling dengan menggunakan rumus slovin. Menurut Sugiyono (2010), Probability sampling adalah teknik pengambilan sampel yang memberikan peluang yang sama bagi setiap unsur (anggota) populasi untuk dipilih menjadi anggota sampel. Besarnya sampel dalam penelitian ini ditentukan dengan rumus Slovin sebagai berikut: Jadi, jumlah keseluruhan responden dalam penelitian ini adalah 209 mahasiswa.

Teknik pengambilan sampel adalah probability sampling dengan menggunakan proportionate stratified random sampling. Menurut Sugiyono (2010) proportionate stratified random sampling adalah teknik yang digunakan bila populasi mempunyai anggota/unsur yang tidak homogen dan berstrata secara proporsional. Untuk menentukan besarnya sampel pada setiap kelas dilakukan dengan alokasi proporsional agar sampel yang diambil lebih proporsional sehingga didapatkan jumlah sampel untuk mahasiswa semester 4 sejumlah 120 dan mahasiswa semester 8 sejumlah 89 .

\section{Metode Pengumpulan Data}

Metode yang digunakan adalah metode survei dengan menggunakan kuisioner yang diberikan kepada responden untuk dijawab. Pertanyaan dalam kuisioner menggunakan skala likert. 


\section{Metode Analisis Data}

Analisis kuantitatif merupakan metode analisis dengan angka-angka yang dapat dihitung maupun diukur. Analisis kuantitatif ini dimaksudkan untuk memperkirakan besarnya pengaruh secara kuantitatif dari perubahan satu atau beberapa kejadian lainnya dengan menggunakan alat analisis statistik. Pengolahan data dengan analisis kuantitatif melalui beberapa tahap.

\section{Uji Instrumen}

\section{Uji Validitas}

Digunakan untuk mengukur valid atau tidaknya suatu kuisioner. Suatu kuisioner dikatakan valid apabila pertanyaan pada kuisioner mampu untuk mengungkapkan sesuatu yang akan diukur oleh kuisioner tersebut (Ghozali,2011). Alat uji yang digunakan pada uji validitas adalah korelasi antara indikator masing-masing pertanyaan dengan total skor dari indikator dalam satu variabel. Ketentuan valid atau tidaknya dapat ditentukan dengan kriteria nilai $\mathrm{r}$ yaitu: (a) Jika $\mathrm{r}$ hitung $>\mathrm{r}$ tabel maka pertanyaan tersebut di anggap valid, dan (b) b. Apabila $r$ hitung < $r$ tabel maka pertanyaan tersebut di anggap tidak valid.

\section{Uji Reabilitas}

Digunakan untuk mengukur suatu kuisioner yang merupakan indikator dari variabel atau konstruk. Suatu kuisioner dikatakan reliabel atau handal apabila jawaban responden atas pernyataan itu konsisten atau stabil dari waktu ke waktu. Suatu variabel dikatakan reliabel dikatakan reliabel jika memiliki Cronbach Alpha > 0,7 (Ghozali, 2011).

\section{Analisis Deskriptif}

Menurut Sugiyono (2004) Analisis deskriptif adalah statistik yang digunakan untuk menganalisa data dengan cara mendeskripsikan atau menggambarkan data yang telah terkumpul sebagaimana adanya. Untuk melakukan analisis deskriptif, dapat menggunakan teknik analisis indeks. Analisis ini bertujuan untuk menggambarkan persepsi responden atas itemitem pertanyaan yang diajukan (Ferdinand, 2006).

\section{Analisis Hipotesis}

Uji Beda t-test digunakan untuk menentukan dua sampel yang tidak berhubungan memiliki nilai rata-rata yang berbeda maupun menguji terdapat perbedaan rata-rata yang berbeda maupun menguji terdapat perbedaan rata-rata dua sampel yang berhubungan. Uji t-test juga merupakan standar eror perbedaan dalam nilai rata-rata terdistribusi secara normal. Yang artinya apakah konsep yang telah dibangun mempunyai nilai rata-rata yang sama ataukah tidak sama secara signifikan (Ghozali, 2011). Jika hasil levene test menunjukkan bahwa variance kedua populasi sama, maka analisis harus menggunakan asumsi equal variance yaitu dengan 
melihat t-hitung dibandingkan dengan tabel (Ghozali, 2011), yaitu: (a) Jika t hitung $>\mathrm{t}$ tabel maka Ho di tolak dan Ha diterima, dan (b) Jika t hitung $<\mathrm{t}$ tabel maka $\mathrm{H} 0$ di terima atau (a) Jika probabilitas > 0,05 maka $\mathrm{H} 0$ di terima, dan (b) Jika probabilitas < 0,05 maka $\mathrm{H} 0$ di tolak dan Ha di terima

\section{HASIL PENELITIAN}

\section{Uji Kualitas Data}

Pengujian validitas instrumen dengan bantuan perangkat lunak SPSS, nilai validitas dapat dilihat pada kolom Corrected Item-Total Correlation. Jika nilai pearson correlation yang diperoleh lebih besar daripada angka kritik ( $\mathrm{r}$ hitung $>\mathrm{r}$ tabel) maka instrumen tersebut dikatakan valid. Angka kritik pada penelitian ini adala $\mathrm{N}-2=30-2=28$ dengan taraf signifikan $5 \%$ atau $\mathrm{df}=(\alpha$, n-2) maka angka kritik untuk uji validitas pada penelitian ini adalah 0,374. Berdasarkan pengujian validitas instrumen, nilai Corrected Item-Total Correlation bernilai positif dan di atas nilai $r$ tabel $(0,374)$ yang artinya semua butir pertanyaan dapat dikatakan valid.

Untuk mengetahui apakah kuesioner tersebut telah reliabel, maka dilakukanlah pengujian reliabilitas kuesioner dengan bantuan komputer program SPSS. Uji reliabilitas dilakukan untuk menunjukkan sejauh mana suatu alat pengukur dapat dipercaya. Secara umum suatu instrumen dikatakan bagus jika memiliki koefisien Cronbach's alpha sebesar $>0,6$. Nilai Croncbach's Alpha untuk variabel anggaran berbasis kinerja (Y), transparansi $\left(\mathrm{X}_{1}\right)$, partisipasi $\left(\mathrm{X}_{2}\right)$, supremasi hukum $\left(\mathrm{X}_{3}\right)$, akuntabilitas $\left(\mathrm{X}_{4}\right)$, dan efektifitas $\left(\mathrm{X}_{5}\right)$ lebih besar dari 0,6 (Croncbach's Alpha > 0,6), maka dapat disimpulkan bahwa instrumen penelitian tersebut realibel.

\section{Hasil Uji Beda}

\section{Hasil Uji Beda Pengetahuan Keuangan Pribadi}

Hasil uji beda pengetahuan keuangan pribadi dapat dilihat pada tabel 1di bawah ini:

Tabel 1. Hasil Uji Beda Pengetahuan Keuangan Pribadi

\begin{tabular}{ccc}
\hline Keterangan & Semester 4 & Semester 8 \\
\hline $\mathrm{N}$ & 120 & 80 \\
Mean & 119,16 & 142,14 \\
St.Dev & 6,793 & 12,194 \\
\hline F Hitung & \multicolumn{3}{c}{32,725} \\
Sig & \multicolumn{3}{c}{0,000} \\
\hline
\end{tabular}

Sumber: Data Diolah

Pengujian pertama dilakukan pada hipotesis pertama yaitu perbedaan pengetahuan keuangan pribadi mahasiswa semester 4 dengan semester 8 . Pengujian dilakukan menggunakan alat uji independent sample test. Hasil 
analisis statistik menunjukkan adanya perbedaan pengetahuaan keuangan pribadi mahasiswa semester 4 dengan semester 8 .

\section{Sikap Keuangan Pribadi}

Pengujian kedua dilakukan pada hipotesis kedua yaitu perbedaan sikap keuangan pribadi mahasiswa semester 4 dengan semester 8. Pengujian dilakukan menggunakan alat uji independent sample test. Hasil analisis statistik menunjukkan tidak ada perbedaan sikap keuangan pribadi mahasiswa semester 4 dengan semester 8 . Hasil uji beda sikap keuangan pribadi dapat dilihat pada tabel 2 di bawah ini:

Tabel 2. Hasil Uji Beda Sikap Keuangan Pribadi

\begin{tabular}{ccc}
\hline Keterangan & Semester 4 & Semester 8 \\
\hline N & 120 & 80 \\
Mean & 53,4 & 164,08 \\
St.Dev & 3,452 & 2,604 \\
\hline F Hitung & \multicolumn{3}{c}{3,476} \\
Sig & \multicolumn{3}{c}{0,064} \\
\hline
\end{tabular}

Sumber: Data Diolah

\section{Perilaku Keuangan Pribadi}

Pengujian ketiga dilakukan pada hipotesis ketiga yaitu perbedaan perilaku keuangan pribadi mahasiswa semester 4 dengan semester 8. Pengujian dilakukan menggunakan alat uji independent sample test. Hasil analisis statistik menunjukkan ada perbedaan perilaku keuangan pribadi mahasiswa semester 4 dengan semester 8 . Hasil uji beda perilaku keuangan pribadi dapat dilihat pada tabel 3 di bawah ini:

Tabel 3. Hasil Uji Beda Perilaku Keuangan Pribadi

\begin{tabular}{ccc}
\hline Keterangan & Semester 4 & Semester 8 \\
\hline N & 120 & 80 \\
Mean & 90,8 & 101,73 \\
St.Dev & 5,599 & 3,175 \\
\hline F Hitung & \multicolumn{3}{c}{17,576} \\
Sig & \multicolumn{3}{c}{0,000} \\
\hline
\end{tabular}

Sumber: Data Diolah

\section{PEMBAHASAN}

\section{Variabel Pengetahuan Keuangan Pribadi}

Hasil dari hipotesis pertama $\mathrm{H}_{1}$ diterima, yaitu terdapat perbedaan pengetahuan keuangan pribadi pada mahasiswa semester 4 dengan semester 8. Hasil penelitian ini sesuai dengan penelitian Marsh (2006) yang menyatakan mahasiswa tingkat akhir memiliki pengetahuan keuangan pribadi yang lebih tinggi daripada mahasiswa tingkat pertama. Hasil 
penelitian ini juga sesuai dengan penelitian Zahroh (2014) yang menyatakan terdapat perbedaan yang signifikan antara mahasiswa semester 3 dan 7 dalam pengetahuan keuangan. Pembelajaran di perguruan tinggi sangat berperan penting dalam proses pembentukan literasi keuangan mahasiswa. Hal ini dapat dilihat bahwa mahasiswa semester 8 memiliki pengetahuan keuangan yang lebih tinggi daripada mahasiswa semester 4 karena adanya pembelajaran yang efektif di perguruan tinggi dimana mahasiswa semester 8 adalah mahasiswa tingkat akhir dan sudah menyelesaikan perkuliahan yang ada selama 8 semester dengan mata kuliah akuntansi dan manajemen dengan jumlah jam dan sks yang lebih tinggi daripada mahasiswa semester 4. Mahasiswa tinggal di lingkungan ekonomi yang beragam dan kompleks sehingga peningkatan kebutuhan pendidikan keuangan sangat diperlukan. Adanya pengetahuan keuangan yang baik sejak dini diharapkan mahasiswa dapat memiliki kehidupan yang sejahtera di masa yang akan datang. Pembelajaran yang efektif dan efisien akan membantu mahasiswa memiliki kemampuan memahami, menilai dan bertindak dalam kepentingan keuangan mereka.

\section{Variabel Sikap Keuangan Pribadi}

Hasil dari hipotesis kedua $\mathrm{H}_{2}$ ditolak, yaitu tidak terdapat perbedaan sikap keuangan pribadi pada mahasiswa semester 4 dengan semester 8 . Hasil penelitian ini tidak sesuai dengan penelitian Marsh (2006) yang menyatakan mahasiswa tingkat akhir menunjukkan sikap keuangan pribadi yang lebih tinggi daripada mahasiswa tingkat pertama. Hasil penelitian ini juga tidak sesuai dengan penelitian Zahroh (2014) yang menyatakan terdapat perbedaan yang signifikan antara mahasiswa semester 3 dan 7 dalam sikap keuangan.

\section{Variabel Perilaku Keuangan Pribadi}

Hasil dari hipotesis pertama $\mathrm{H}_{3}$ diterima, yaitu terdapat perbedaan perilaku keuangan pribadi pada mahasiswa semester 4 dengan semester 8 . Hasil penelitian ini sesuai dengan penelitian Marsh (2006) yang menyatakan mahasiswa menunjukkan perilaku keuangan pribadi yang lebih tinggi daripada mahasiswa tingkat pertama. Hasil penelitian ini juga sesuai dengan penelitian Zahroh (2014) yang menyatakan terdapat perbedaan yang signifikan antara mahasiswa semester 3 dan 7 dalam perilaku keuangan. Bagi sebagian besar mahasiswa, masa kuliah adalah saat pertama mereka mengelola keuangannya sendiri tanpa adanya pengawasan dari orang tua. Mahasiswa akan menghadapi permasalahan yang mungkin baru dan menghadapi lingkungan yang baru tanpa adanya pengawasan dan dukungan dari orang tua. Mahasiswa harus bisa secara mandiri mengatur keuangannya dengan baik dan juga harus bisa bertanggung jawab atas keputusan yang telah mereka buat. Permasalahan-permasalahan keuangan yang sering timbul pada mahasiswa adalah mereka belum memiliki pendapatan, 
sebagian dari mahasiswa adalah mereka belum memiliki pendapatan, sebagian dari mahasiswa masih bergantung kepada orang tua. Selain itu, sikap boros dari mahasiswa merupakan permasalahan yang sering dihadapi.

\section{KESIMPULAN DAN SARAN}

Berdasarkan pembahasan hasil penelitian, maka dapat diambil kesimpulan adalah sebagai berikut: (1) Terdapat perbedaan pengetahuan keuangan pribadi antara mahasiswa semester 4 dengan semester 8 (2) Tidak terdapat perbedaan sikap keuangan pribadi antara mahasiswa semester 4 dengan semester 8 (3) Terdapat perbedaan perilaku keuangan pribadi antara mahasiswa semester 4 dengan semester 8 . Sedangkan saran dalam penelitian ini adalah pembelajaran yang efektif diperlukan untuk meningkatkan pengetahuan keuangan mahasiswa. Untuk penelitian selanjutnya perlu memasukkan variabel demografi untuk menunjukkan perbedaan pengetahuan keuangan yang lebih signifikan

\section{DAFTAR PUSTAKA}

Augusty, Ferdinand, 2006, Metode Penelitian Manajemen, Semarang: Badan Penerbit Universitas Diponegoro.

Behrman, J.R., O.S. Mitchell, C.K. Soo, dan D. Bravo. (2012) The Effects Of Financial Education And Financial Literacy: How Financial Literacy Affects Household Wealth Accumulation. American Economic Review: Paper and Proceedings.

Byrne, A. 2007. Employee Saving and Investment Decisions in Defined Contribution Pension Plans: Survey Evidence from the U.K. Financial Services Review 16 (2007) 19-4.

Chen, H dan R. P. Volpe. 1998. An Analysis of Personal Financial Literacy Among College Students. Financial Service Review. 11: 289-307.

Goss, B. 2001. 11 Top Financial Planning Mistakes And How To Avoid Them Chiropractic Economics. (Retrifed from: http://www.chiroeco.com/article/1999/Nov/Fin2.php.).

Navickas, M., T. Gudaitis dan E. Krajnakova. 2014. Influence Of Financial Literacy On Management Of Personal Finance In A Young Household. Business: Theory and Practice 15 (1):32-40.

Ghozali, Imam, 2011, Ekonometrika: Teori Konsep dan Aplikasi dengan SPSS 20, Semarang: Badan Penerbit Universitas Diponegoro.

Kapoor, J.R., L.R. Dlabay, dan Hughes, R.J. 2011. Personal Finance. New York: Mc Graw Hill.

Lawrence Gitman, Principle of Finance, (11th ed).(2002). Prentice Hall, New Jersey.

Lusardi, A dan O.S. Mitchell. 2014. The Economic Importance of Financial Literacy: Theory and Evidence. Journal of Economic Literature 2014, 52(1), 5-44 
Navickas, M., T. Gudaitis dan E. Krajnakova. 2014. Influence Of Financial Literacy On Management Of Personal Finance In A Young Household. Business: Theory and Practice 15 (1):32-40.

Otoritas Jasa Keuangan. 2013. OJK Perkuat Upaya Inklusi dan Perluasan Akses Keuangan Melalui Literasi Keuangan. Majalah OJK Edisi November. (Retrifed from http://sikapiuangmu.ojk.go.id/public/content/files/Majalah-OJK-2.pdf.).

Otoritas Jasa Keuangan. 2013. Perencanaan Keuangan Ibu Rumah Tangga. (Retrifedfrom:http://sikapiuangmu.ojk.go.id/public/content/files/bukuper encanaankeuanganirt.pdf.)

Rita dan Santoso: literasi Keuangan dan Perencanaan Keuangan pada Dana Pendidikan Jurnal Ekonomi/Volume XX, No. 02, Juli 2015: 212-227

Conference on Teacher Education; Join Conference UPI \& UPSI Bandung, Indonesia, 8-10 November 2010.

Sugiyono, 2013, Metode Penelitian Bisnis, Bandung: Alfabeta.

Zahroh, Fatimatus, 2014, Menguji Tingkat Pengetahuan Keuangan, Sikap Keuangan Pribadi, Dan Perilaku Keuangan Pribadi Mahasiswa jurusan Manajemen Fakultas Ekonomika Dan Bisnis Semester 3 Dan Semester 7, Skripsi, Semarang: Fakultas Ekonomika Dan Bisnis Universitas Diponegoro. 